JURNAL EXPLORE IT!

Vol. 11 No. 2 - Desember 2019

p-ISSN 2086-3489 (Print)- e-ISSN 2549-354X (Online)

Avaiable online at

http://jurnal.yudharta.ac.id/v2/index.php/EXPLORE-IT/

\title{
BUSINESS PROCESS SIMULATION IN PUBLIC SCHOOLS USING THE BUSINESS PROCESS IMPROVEMENT METHOD (BPI) AND ANYLOGIC SOFTWARE
}

\author{
Usman Jeylani' $^{\text {), }}$ M Falihul Isbah ${ }^{2)}$, Muhammad Ainul Yaqin ${ }^{3)}$, Pinkan Veri Diana E ${ }^{4)}$ \\ 1),2),3),4) Department of Informatics, Faculty of Science and Technology \\ Maulana Malik Ibrahim State Islamic University of Malang \\ Gajayana Street No. 50 Malang 65144 Tel. +62 (341) 551-354 \\ Email : \\ usmanjeylani@gmail.com,16650008@ student.uin-malang.ac.id, yaqinov@ti.uin-malang.ac.id , \\ 16650110@student.uin-malang.ac.id
}

\begin{abstract}
School Is an institution where people learn like reading, writing and learning to behave well, the school has a system of social interaction in an organizational relationship, in every institution must have a business process that is run in order to achieve the vision and mission specified, the business process has activities that are done to provide services or products. In this study, the aim is to analyze business process systems in schools by designing school business process simulation scenarios and then implementing the design of AnyLogic Software and can contribute in optimizing the management of business processes within schools, where processes are more structured and systematic. The method used in this study is the Business Process Improvement (BPI) Method with the aim of eliminating errors, and providing competitive benefits by improving business processes. In applying the BPI method, the results obtained are recommendations for improving school business processes: 1) Adding Buses to schools. 2) Addition of School Cooperative Staff to transport goods. 3) Adding Cashiers in School Cooperatives.
\end{abstract}

Keywords: Simulation, School, AnyLogic, BPI, Business Process

\section{INTRODUCTION}

School is an institution or place for learning such as reading, writing and learning to behave well. Schools are also an integral part of a society that is dealing with real conditions that exist in society today. School is also the second environment where children practice and grow their personalities. The school has a system of social interaction of an entire organization consisting of personal interactions related together in an organizational relationship, in every institution must have a business process that is run in order to achieve the vision and mission specified, the business process has activities carried out to provide services or products. its products. Business process is a structured work that is interrelated to solve certain problems, in a business process generally involves mapping the process, sub-processes to the level of activity or activity. According to Pall (1987) the definition of a business process is "organizing human resources, materials, energy, equipment, and procedures into work activities that are designed to produce the specified end result" (work products) ".[1]

According to Weske(2007) Each business process is formed by one organization, but the business process can interact with business processes in other organizations. [2] With a business process including a series of activities starting from a survey of business processes and the organizational and technical environment, then business process simulations can provide a structured and interrelated work or activity design to solve a problem in a business process, simulations on business processes are used to assess the dynamic behavior of a process over time, that is development of processes and performance of resources as a reaction to changes or fluctuations in the environment or certain system parameters.

This research aims to analyze the business process systems in schools by designing school business process simulation scenarios and then implementing business process simulation designs and can contribute in optimizing the management of business processes within schools, where processes are more structured and systematic.

\section{RELATED RESEARCH EVER CONDUCTED}

Based on a similar research from Arofian Taufi Helmi (2018), in his research on Analysis and Modeling of Business Processes Using Business Process Improvement (BPI) at the Tutoring Institute (Case Study: Prism Learning Guidance Institute)[3], the prism guidance institute is one of the current study guides This is growing, but in carrying out business processes do not have a standard business process and clear. In this study aims to model and conduct business process simulations on prism learning guidance using BPMN, the research begins with literature study and collection through 
interviews. Then do the modeling and simulation of business processes using the BPI approach, modeling and simulating business process proposals and comparing the results of process simulations. The results obtained are modeling four business processes that will be improved later, proposed business process models using BPI techniques, the results of comparison of current business process simulations.

In Tri Susanto's research (2018), Analysis and Improvement of Business Processes Using the Business Process Improvement (BPI) Method (Case Study: PT. Wonojati Wijoyo)[4], Business Process Improvement (BPI) can be used to help someone improve business processes, BPI is a systematic framework that organizations can use to help make progress in implementing business processes.

Then in the research of Muhammad Ainul Yaqin (2019) concerning Business Process Simulation, it explains about the simulation of business process models in the Travel Agency game[5], in his research using the Business Procurement Improvement (BPI) method for the analysis and modeling of business processes and the BPMN (Business Process Model and Notation) method. as a tool to describe or create a graphical model of business operations where there are activities and flow controls that define work order. with the use of these methods it can be seen the flow of business processes and recommendations for improvement on problems in the business process of the Travel Agency game. This study conducted an experiment on Anylogic software, namely by adding queuing capacity in the waiting room and the results of this experiment will be compared with the simulation game Travel Agency, with additional capacity, the number of customer output is more than before and is expected to meet targets based on the time available.

\section{RESEARCH METHODS}

The steps taken in the research method are as follows:

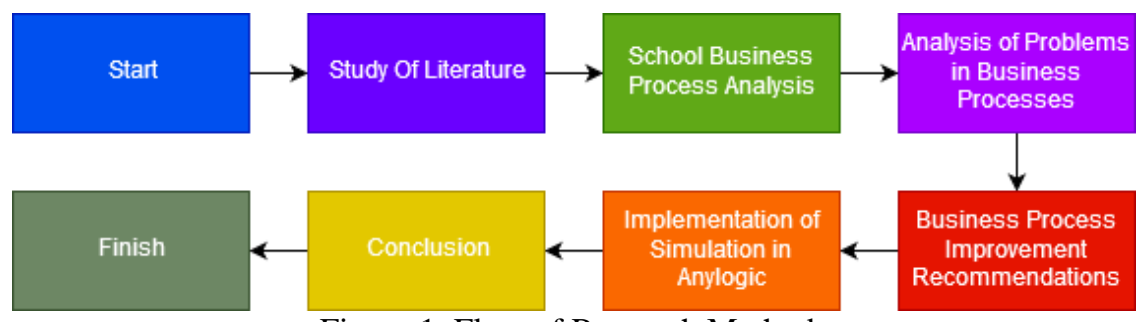

Figure 1. Flow of Research Methods

In this study using the Business Process Improvement (BPI) method with the aim of eliminating mistakes, and providing competitive advantages with improving business processes. that is:

- Organizing for Improvement

improvement organizers who aim to manage internal and external business processes to become better in an organization.

- Understanding the Process

Phase to understand and explore all dimensions of the current business process

- Streamlining (Process Simplification)

Phase to improve or increase the effectiveness, efficiency and adaptability of business processes.

- Measurements and controls

Measurement and control of business processes is carried out to control the course of business processes by checking and measuring the predicted targets to be achieved by the organization.

- Countinuous Improvement

Continuous improvement is carried out with the aim to achieve the implementation of further improvement processes with various processes such as changes, deleting, adding processes, and so on.

After that, to measure and evaluate the performance of business processes, matrix testing criteria (Criteria Testing) is used, Testing criteria is a tool in the form of tables or matrices that can be used to determine the parts that must be repaired. 
Vol. 11 No. 2 - Desember 2019

p-ISSN 2086-3489 (Print)- e-ISSN 2549-354X (Online)

Avaiable online at

http://jurnal.yudharta.ac.id/v2/index.php/EXPLORE-IT/

\subsection{School Business Process Analysis}

\section{DISCUSSION}

A. Following is the business process flow of teacher and student activities at school:

1. Students and teachers go to school

2. Students put their bags in class and the teacher goes to the office

3. Students and teachers gather in the field to conduct the ceremony

4. Students return to class

5. The teacher returns to the office to prepare for teaching and learning activities

6 . The teacher goes to class to teach

7. Starting teaching and learning activities

8. School break

9. Students leave (cooperative, canteen, play area)

10. The teacher returns to the office

11. Students return to class

12. The teacher returns to class to teach

13. teaching and learning process

14. ishoma

15. Entering the classroom continues teaching and learning

16. Teaching and learning process

17. After school

B. The flow of business processes in school cooperatives

1. Truck comes to deliver goods

2. Workers come to collect goods

3. Workers place items on the shelves

4. The truck leaves the cooperative

\subsection{Matriks Criteria Testing}

Table. 1. Matriks Criteria Testing

\begin{tabular}{|c|c|c|c|c|c|c|}
\hline \multirow[t]{2}{*}{$\mathrm{NO}$} & \multirow[t]{2}{*}{ Business process } & CSf & DATA & TIME & ACTIVITY & \multirow[t]{2}{*}{ TOTAL } \\
\hline & & Weight & 3 & 3 & 3 & \\
\hline \multirow[t]{2}{*}{1.} & $\begin{array}{c}\text { Business Processes } \\
\text { Go to School }\end{array}$ & Impact & 2 & 3 & 3 & \\
\hline & & $\begin{array}{l}\text { Weight } \\
\text { X } \\
\text { Impact }\end{array}$ & 6 & 9 & 9 & 24 \\
\hline \multirow[t]{2}{*}{2} & $\begin{array}{l}\text { Business Processes } \\
\text { Teaching and } \\
\text { Learning Activities }\end{array}$ & Impact & 1 & 1 & 3 & \\
\hline & & $\begin{array}{c}\text { Weight } \\
X \\
\text { Impact }\end{array}$ & 3 & 3 & 9 & 15 \\
\hline \multirow[t]{2}{*}{3} & $\begin{array}{c}\text { School Canteen } \\
\text { Business Process }\end{array}$ & Impact & 2 & 2 & 2 & \\
\hline & & $\begin{array}{c}\text { Weight } \\
\text { X } \\
\text { Impact }\end{array}$ & 6 & 6 & 6 & 18 \\
\hline \multirow[t]{2}{*}{4} & $\begin{array}{c}\text { School } \\
\text { Cooperative } \\
\text { Business Process }\end{array}$ & Impact & 3 & 3 & 3 & \\
\hline & & $\begin{array}{c}\text { Weight } \\
\text { X } \\
\text { Impact }\end{array}$ & 9 & 9 & 9 & 27 \\
\hline
\end{tabular}


JURNAL EXPLORE IT!

Vol. 11 No. 2 - Desember 2019

p-ISSN 2086-3489 (Print)- e-ISSN 2549-354X (Online)

Avaiable online at

http://jurnal.yudharta.ac.id/v2/index.php/EXPLORE-IT/

In this study, choosing 2 business processes, that is the business processes going to school and the school cooperative business processes, with the value of processes 24 and 27.

\subsection{Analysis of Problems in Business Processes}

In making business process simulations in schools there are problems that occur in business processes, that is:

Table 2. Business Process Problems in Schools

\begin{tabular}{|c|c|c|}
\hline \multirow[t]{2}{*}{ No } & \multicolumn{2}{|c|}{ Business Process in Schools } \\
\hline & Problem & Risk \\
\hline 1 & $\begin{array}{l}\text { Cooperative employees to arrange } \\
\text { goods }\end{array}$ & $\begin{array}{c}\text { Work is demanded fast because more and more } \\
\text { customers are served }\end{array}$ \\
\hline 2 & Cooperative cashier & Many queues waiting \\
\hline 3 & Time of arrival of students at school & $\begin{array}{l}\text { Student delay due to the distance between home } \\
\text { and school }\end{array}$ \\
\hline
\end{tabular}

\section{RESULT AND IMPLEMENTATION OF ANYLOGICS}

\subsection{Business Process Improvement Recommendations}

Table 3. Business Process Improvement Recommendations

\begin{tabular}{|c|c|c|c|}
\hline No & \multicolumn{3}{|c|}{ Business Process in Schools } \\
\cline { 2 - 4 } & Problem & Repair Techniques & Information \\
\hline 1 & $\begin{array}{c}\text { Cooperative employees to } \\
\text { transport goods }\end{array}$ & $\begin{array}{c}\text { The addition of cooperative } \\
\text { employees to arrange goods }\end{array}$ & $\begin{array}{c}\text { In the process of preparing } \\
\text { goods faster }\end{array}$ \\
\hline 2 & $\begin{array}{c}\text { Cooperative cashier } \\
\text { Cashier addition }\end{array}$ & $\begin{array}{c}\text { The payment process is getting } \\
\text { faster }\end{array}$ \\
\hline 3 & $\begin{array}{c}\text { Time of arrival of students } \\
\text { at school }\end{array}$ & School Bus Addition & Reduces delays and worries \\
\hline
\end{tabular}

\subsection{Application of Simulation in Analogic}

Following is the application of school business process simulation to Analogic:

A. Students go to school by Bus

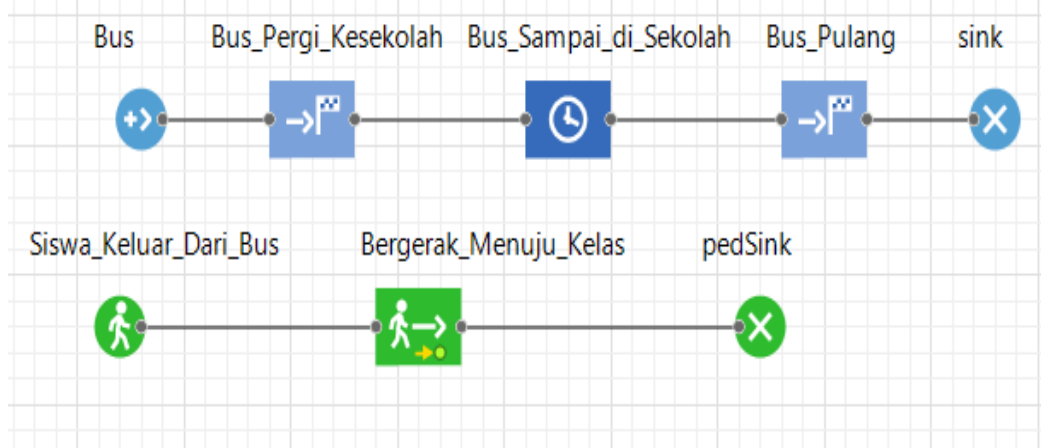

Figure 2. Bus Going to School Process

Information:

1. Bus, Bus Input

2. Bus_Pergi_Kesekolah, Process the bus to school

3. Bus_Sampai_di_Sekolah, Bus arrived at school

4. Bus_Pulang, Bus leaves school 
JURNAL EXPLORE IT!

Vol. 11 No. 2 - Desember 2019

p-ISSN 2086-3489 (Print)- e-ISSN 2549-354X (Online)

Avaiable online at

http://jurnal.yudharta.ac.id/v2/index.php/EXPLORE-IT/

5. Siswa_Keluar_Dari_Bus, Process students out of the bus

6. Bergerak_Menuju_Kelas, Student move to class

7. Done

B. Student and Teacher Activities

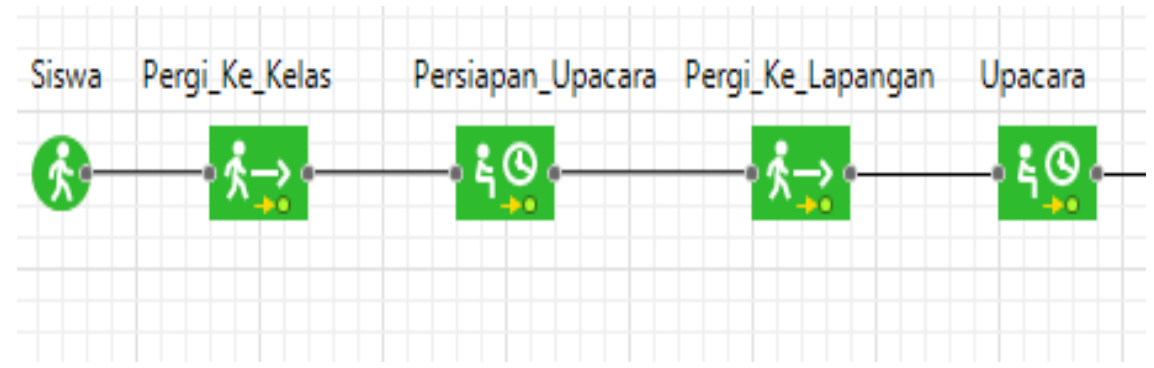

Figure 3. The Process of Students Arrival Up to the Ceremony

Information:

1. Siswa, Early appearance of students in school

2. Pergi_Ke_Kelas, Students head to class

3. Persiapan_Upacara, Students wait for the ceremony time in class

4. Pergi_Ke_Lapangan, Students leave

5. Upacara, Students carry out ceremonies in the field

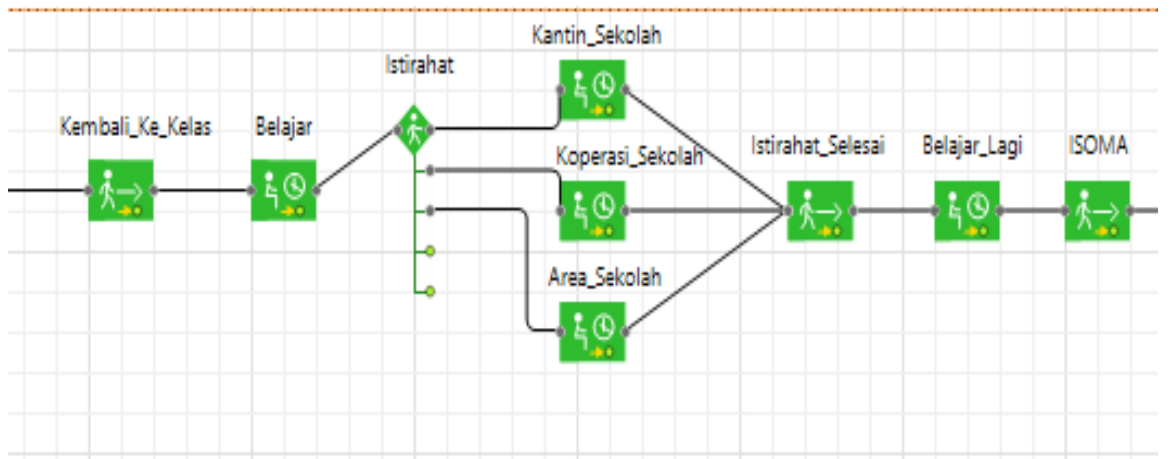

Figure 4. Process of Activities After the Ceremony to the Ishoma Activity

Information:

1. Kembali_Ke_Kelas, Students return to class

2. Belajar, Students do learning activities in class

3. Istirahat, selection of student processes to the school canteen, school cooperatives, school area

4. Kantin_Sekolah, Students rest in the canteen

5. Koperasi_Sekolah, Students buy necessities in cooperatives

6. Area_Sekolah, Students rest around the school area

7. Istirahat_Selesai, Students return to class

8. Belajar_Lagi, Students do teaching and learning activities

9. ISOMA, Rest, Pray, Eat 


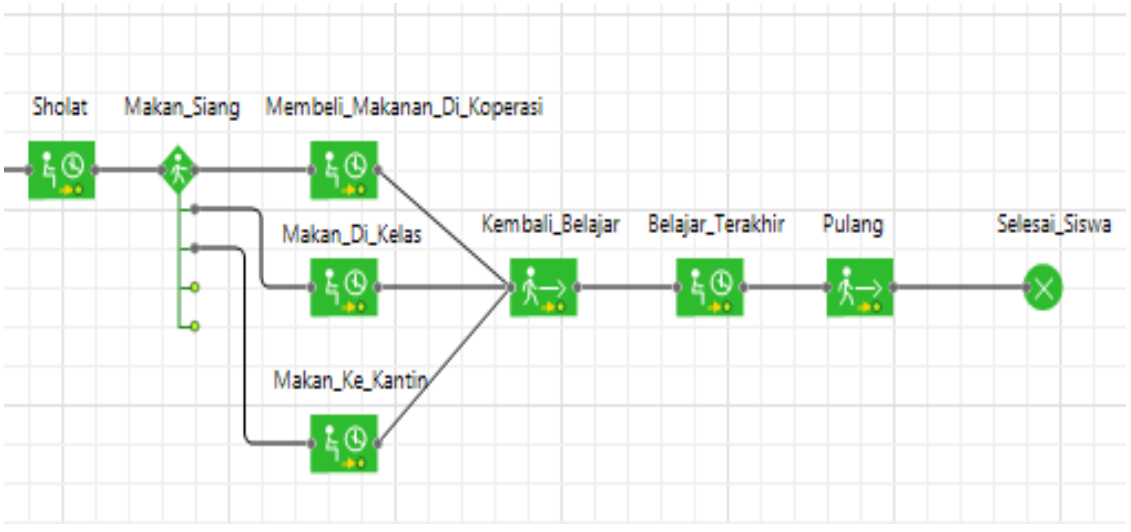

Figure 5. The process of Ishoma activities until returning from school

Information:

1. Sholat, Students go to the school mosque

2. Makan_Siang, Process Students do break activities by choosing a place to rest

3. Membeli_Beli_Makanan_Di_Koperasi, Students buy food at the cooperative

4. Makan_Di_Kelas, Students have lunch in class

5. Makan_Ke_Kantin, Students buy food in the school canteen

6. Kembali_Belajar, Students return to class for teaching and learning activities

7. Belajar_Terakhir, Students end teaching and learning activities

8. Pulang, Students leave school

9. Done

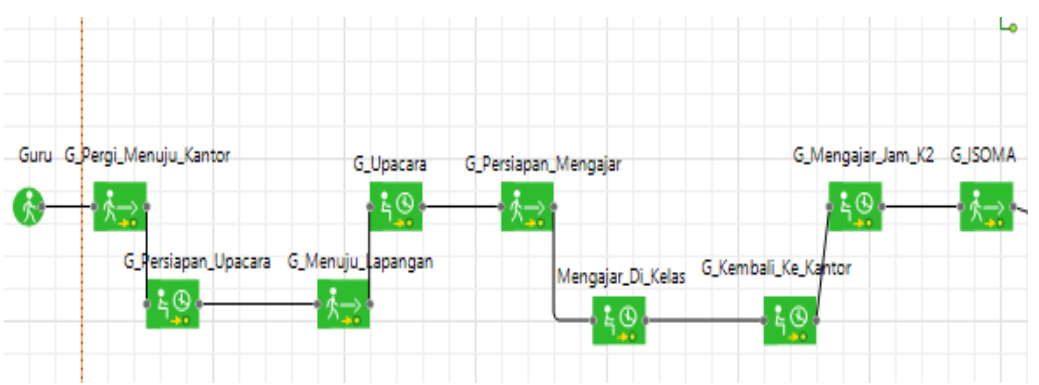

Figure 6. The Process of the Teacher's Arrival to the Ishoma Activity

Information:

1. Guru, The arrival of the teacher at school

2. G_Pergi_Menuju_Kantor, The teacher goes to the office

3. G_Persiapan_Upacara, The teacher in the office is preparing for the ceremony

4. G_Upacara, The teacher carries out the ceremony

5. G_Persiapan_Mengajar, The teacher prepares activities for teaching

6. Mengajar_Di_Kelas, The teacher carries out teaching activities

7. G_Kembali_Ke_Kantor, The teacher returns to the office after teaching

8. G_Mengajar_Jam_K2, The teacher returns to the classroom to carry out teaching activities

9. G_ISOMA, The teacher carries out ishoma activities with students

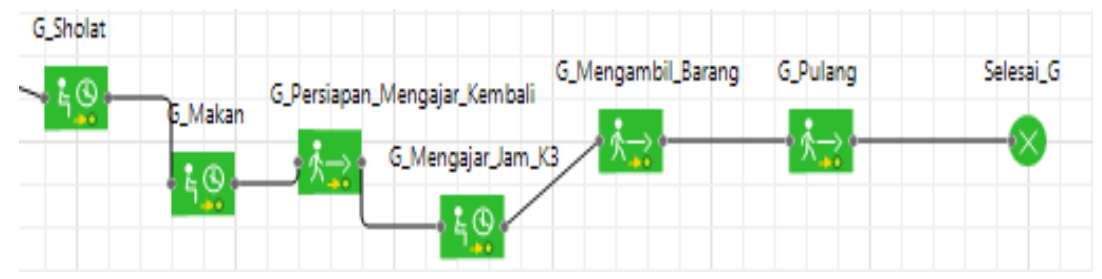

Figure 7. Ishoma Processes After School

Information:

1. $G_{-}$Sholat, The teacher performs prayers 
JURNAL EXPLORE IT!

Vol. 11 No. 2 - Desember 2019

p-ISSN 2086-3489 (Print)- e-ISSN 2549-354X (Online)

Avaiable online at

http://jurnal.yudharta.ac.id/v2/index.php/EXPLORE-IT/

2. $\quad G_{-}$Makan_Ke_Kantin, The teacher does the eating

3. G_Persiapan_Mengajar_Kembali, The teacher prepares learning activities

4. $G_{-}$Mengajar_Jam_K3, The teacher carries out teaching activities

5. G_Mengambil_Barang, The teacher returns to the office

6. $\quad G \_$Pulang, The teacher leaves school

7. Selesai_G, Done

C. Business Processes in Cooperatives

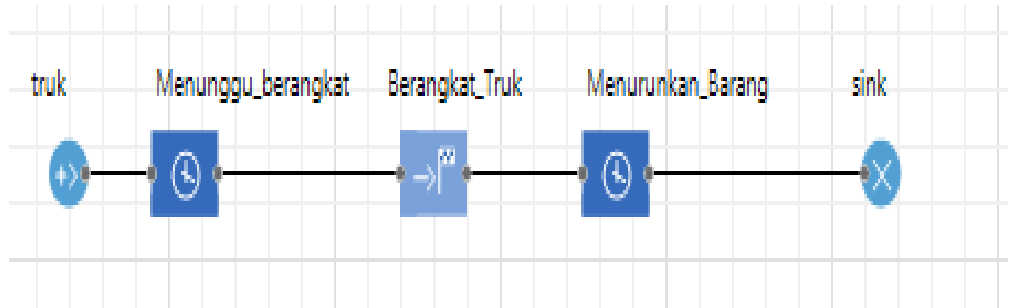

Figure 8. The Arrival Process of Delivery Goods Truck

Information :

1. truck, Transporting goods to be sent to the cooperative

2. Menunggu_berangkat, Waiting for the goods to be transported is finished

3. Berangkat_Truk, The truck departs to send goods

4. Menurunkan_Barang, Lowering goods to the cooperative

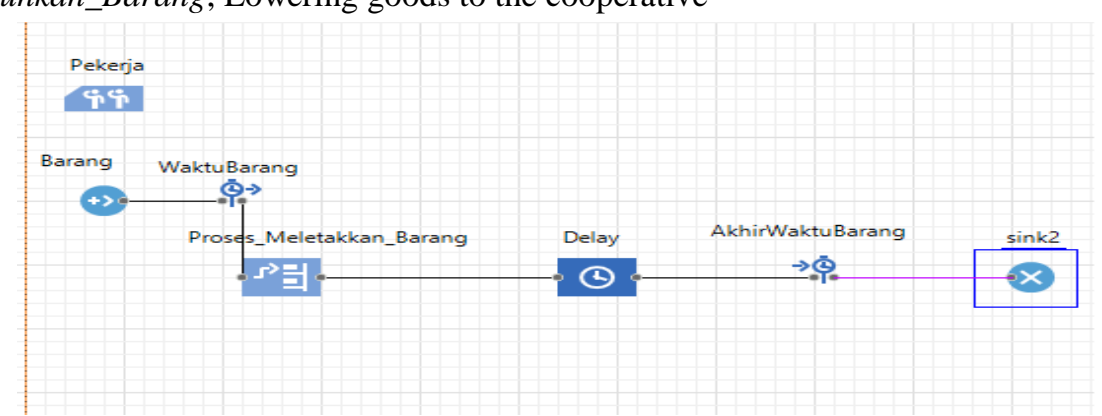

Figure 9. The Process of Transporting Goods to Shelves

Information :

1. Pekerja, The process of inputting the number of workers

2. Barang, Early emergence of goods

3. WaktuBarang, Process time data of goods

4. Proses_Meletekkan_Barang, The process of workers transporting goods to the cooperative shelves

5. Delay, Proses Waiting for goods until students arrive to collect goods

6. AkhirWaktuBarang, Data processing time ends

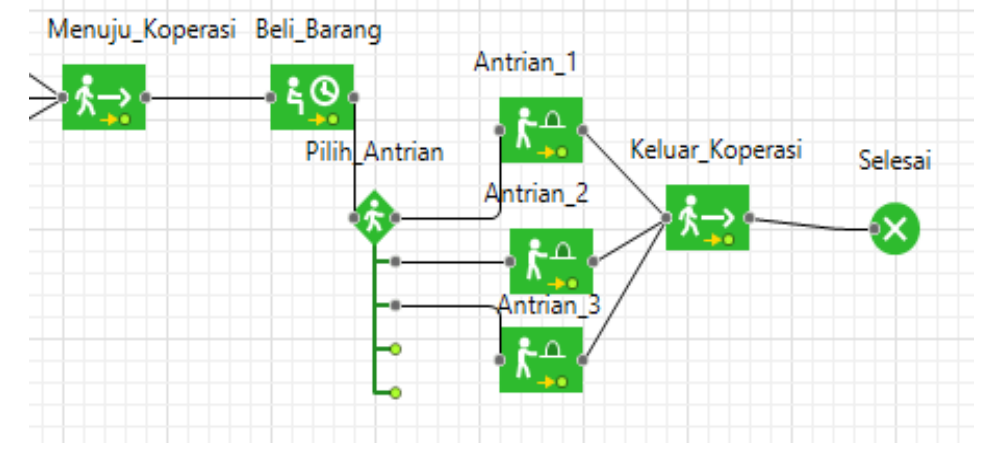

Figure 10. The Process of Students Buying Goods in Cooperatives

Information : 
JURNAL EXPLORE IT!

Vol. 11 No. 2 - Desember 2019

p-ISSN 2086-3489 (Print)- e-ISSN 2549-354X (Online)

Avaiable online at

http://jurnal.yudharta.ac.id/v2/index.php/EXPLORE-IT/

1. Menuju_Koperasi, Students head to the cooperative

2. Beli_Barang, Students buy goods

3. Pilih_Antrian, Students choose where to wait in line for payment

4. Antrian_1, The Process of Students Queuing at Cashiers 1

5. Antrian_2, The Process of Students Queuing at the Cashier 2

6. Antrian_3, The Process of Students Queuing at the Cashier 3

7. Keluar_Koperasi, Students leave the cooperative

\section{CONCLUSION}

Based on the results of the discussion in this study the following conclusions can be drawn:

1. Application of School Business Process Simulation found Problems that occur and Solutions for business process improvement in schools using the BPI (Business process improvement) method, where many problems are caused by time inefficient so that it can hamper the business process.

2. In the application of School Business Process Simulation using Anylogic Software there are shortcomings in which the use of limited time, that is the Ped Pedrian Library Tool in Anylogic limits the Run Simulation process to only 1 Minute.

\section{REFERENCES}

[1]. Pall G.A. “Quality Press Management”. Englewood Cliffs, New Jersey: Prentice- Hall, 1987.

[2]. Mathias Weske, “Business Process Management: Concepts, Languages, Architectures” 2012, XIV, 403 p. 300 illus., Hardcover ISBN: 978-3-642-28615-5, eBook ISBN: 978-3-642-28616-2 (c) Springer-Verlag Berlin Heidelberg 2012, 2007.

[3]. Helmi, Arofian Taufi, “Analisis dan Pemodelan Proses Bisnis Menggunakan Business Process Improvement (BPI) Pada Lembaga Bimbingan Belajar (Studi Kasus: Lembaga Bimbingan Belajar Prisma)”, Jurnal Pengembangan Teknologi Informasi dan Ilmu Komputer Vol. 2, No. 10, Oktober 2018, Malang: Universitas Brawijaya.

[4]. Susanto, T., Pramono, D., \& Setiawan, N. Y. "Analisis dan Perbaikan Proses Bisnis Menggunakan Metode Business Process Improvement (BPI)(Studi Kasus: PT. Wonojati Wijoyo)”. Jurnal Pengembangan Teknologi Informasi dan Ilmu Komputer e-ISSN, 2548, 964X. (2018).

[5]. Yaqin, M. A., Adawiyah, R., Ningrum, W. A., \& Janan, A. "Simulasi Model Proses Bisnis pada Permainan Travel Agency”. Prosiding SENIATI, 5(2), 80-85. (2019). 